\title{
Analiza utjecaja mikroklimatskih uvjeta u učionicama na rezultate vrednovanja učenika
}

\author{
Bojan Banić, Janja Banić \\ Prva gimnazija Varaždin \\ Petra Preradovića 14
}

bojan.banic@skole.hr,ravnatelj@gimnazija-varazdin.skole.hr

\author{
Vesna Novosel-Martinić, Andreja Veršić \\ Prva gimnazija Varaždin \\ Petra Preradovića 14
}

vesna.novosel-martinic@skole.hr,andreja.versic@skole.hr

\begin{abstract}
Sažetak
U školskoj godini 2018./2019. u Prvoj gimnaziji Varaždin provedeno je istraživanje mikroklimatskih uvjeta na rezultate vrednovanja učenika. Cilj našeg projekta je dokazati ili opovrgnuti utjecaj mikroklime na uspješnost učenika i to u konkretnim situacijama, odnosno prilikom uobičajenog načina provjera znanja: pisanih provjera. Budući da se i ispiti državne mature u ovom trenutku temelje na takvom modelu provjere znanja, smatramo da je važno identificirati korelaciju između mikroklime i uspješnosti učenika na provjeri znanja, a u slučaju potvrde značajnog utjecaja doprinijeti i razvoju standarda uređenja postojećih školskih prostora ili izgradnji novih. Ispitivani mikroklimatski uvjeti bili su temperatura, relativna vlažnost, strujanje zraka. Testiranje je provedeno u 10 različitih učionica i 5 različitih predmeta ili skupina predmeta. Rezultati ukazuju na lošije rezultate vrednovanja pri većim odstupanjima od preporučenih vrijednosti promatranih mikroklimatskih uvjeta.
\end{abstract}

Ključne riječi: Prva gimnazija Varaždin; mikroklimatski uvjeti zatvorenih prostora; toplinska ugodnost; eksperimentalna mjerenja; vrednovanje znanja učenika.

\section{Uvod}

Tijekom 2015. i 2016. godine Prva gimnazija Varaždin provela je istraživanje u sklopu osmišljavanja „Strategije razvoja Prve gimnazije Varaždin“ među učenicima, djelatnicima, roditeljima i bivšim učenicima škole. Cilj je bio Data Mining Strengths Weaknesses Opportunities Threats (DM SWOT) metodom identificirati varijable koje imaju najveći utjecaj na uspješnost učenika. Između ostalog, rezultati su pokazali kako je jedna od tih varijabli i da se učenici u školi osjećaju ugodno, te da ona može povećati uspješnost za $10 \%$. Rezultati su dobiveni na način da su učenici sličnih profila i uspjeha istog usmjerenja na istim predmetima kod istih nastavnika postizali u prosjeku za $10 \%$ bolje rezultate prilikom različitih oblika vrednovanja i to samo zato jer su se osjećali ugodnije na satu. Jedan od razloga boljeg osjećaja ugode bili su izvođenje nastave u učionici s preporučenim mikroklimatskim uvjetima jer je poznato da većina škola u Hrvatskoj, ali i u svijetu, nije projektirana prema potrebnim normama za razvoj termodinamičkih sustava u zgradama. Od tada intenzivno radimo na uređenju učeničkih prostora, unapređivanju odnosa i razvoju dodatnih mogućnosti $s$ ciljem stvaranja poticajne atmosfere. Na ugodan osjećaj svakako utječe $\mathrm{i}$ mikroklima, posebice u središtima odgojno obrazovnog rada - učionicama. U prilog tome govore rezultati postojećih istraživanja (De Giuli et al., 2014)(Grillo et al., 2003)(Ole Fanger, 1970). Zbog svega navedenog prijavili smo se na donacijski natječaj pod nazivom "Generacija Next” („Generacija Next“, 2019) u kategoriji „Digitalne inovacije uz Internet stvari“ kako bi u slučaju dobivanja opreme proveli istraživanje $i$ došli do određenih zaključaka. 


\section{Cilj istraživanja}

Cilj našeg projekta je dokazati ili opovrgnuti utjecaj mikroklime na uspješnost učenika i to u konkretnim situacijama, odnosno prilikom uobičajenog načina provjera znanja: pisanih provjera. Budući da se i ispiti državne mature u ovom trenutku temelje na takvom modelu provjere znanja, smatramo da je važno identificirati korelaciju između mikroklime i uspješnosti učenika na provjeri znanja, a u slučaju potvrde značajnog utjecaja doprinijeti i razvoju standarda uređenja postojećih školskih prostora ili izgradnji novih. Ispitivani mikroklimatski uvjeti bili su temperatura, relativna vlažnost i strujanje zraka (Vučinić et al., n.d.) jer su oni u brojnim istraživanjima (De Giuli et al., 2014) (Grillo et al., 2003) (Hamzah et al., 2020) (Ole Fanger, 1970) pokazatelj kvalitete rada u učionici kao radnog prostora i to u 10 različitih učionica, s obzirom na specifičnost škole. Međutim, za potrebe ovog rada ćemo obraditi samo osnovne elemente mikroklime, a to su temperatura, relativna vlažnost i strujanje zraka.

Cilj će biti postignut provođenjem sljedećih koraka:

1. kvantitativno izmjeriti mikroklimatske uvjete (temperatura, vlažnost i strujanje zraka) u testiranim učionicama,

2. analizirati utjecaj mikroklimatskih uvjeta na rezultate pisanih provjera znanja u odabranim razrednim odjelima i iz odabranih predmeta (matematika, hrvatski jezik, društveni predmeti, strani jezici i informatika),

3. predložiti model budućeg postupanja temeljem dobivenih rezultata istraživanja.

\section{Metodologija istraživanja}

Metodologiju istraživanja podijelili smo u 3 dijela, a to su:

- priprema materijala,

- prikupljanje podataka, i

- analiza podataka i razvoj modela.

\subsection{Priprema materijala}

Dobivanjem dijela opreme na natječaju, dio opreme bilo je potrebno dokupiti kako bismo složili 10 kompleta i uspješno proveli istraživanje. Konačno, istraživanje je provedeno pomoću sljedeće opreme:

- Arduino MKR1000 - Arduino mikrokontroler,

- DHT22 - osjetnici za temperaturu (od -40 do $+80^{\circ} \mathrm{C}$ s preciznošću od $\pm 0,5^{\circ} \mathrm{C}$ ) i vlagu (od 0 do $100 \%$ ) frekvencije $0,5 \mathrm{~Hz}$,
- Wind sensor Rev. P MD0555 - osjetnik brzine strujanja zraka (od 0 do približno $240 \mathrm{~km} / \mathrm{h} \mathrm{s}$ preciznošću od $\pm 0,1 \%$ ).

Nakon nabave kompleta opreme bilo ih je potrebno testirati i kalibrirati kao bi rezultati mjerenja bili što relevantniji. To je učinjeno na način da su svi setovi bili nekoliko dana u istoj učionici, odnosno tako dugo dok svi setovi nisu pokazivali rezultate približne točnosti od $99 \%$. Idući korak bio je odabir odgovarajućih učionica u koje će se postaviti. Budući da je naša škola prilično velika - sastoji se od starog $i$ novog (dograđenog) dijela (slike 1 i 2), ima 2 kata u starom dijelu te 3 kata s međukatovima u novom dijelu kao i brojne druge specifičnosti, kao što su npr. geometrija učionica (pravokutna i približnih površina cca $60 \mathrm{~m} 2$ ), udio staklenih površina (približnih dimenzija u omjeru na veličinu učionice samo s jedne strane zida u svim učionicama), te vrsta radijatora ( $u$ starom dijelu škole od lijevanog željeza, u novom dijelu aluminijski, ali približnih udjela u odnosu na veličinu učionice), odabir učionica nije bio baš jednostavan. Tako smo najprije, uz pomoć učenika, polaznika fakultativne nastave predmeta "Statistika“, proveli anketu među profesorima da bismo dobili uvid $u$ učionice $u$ kojima je više ili manje ugodno raditi.

Na slikama 1 i 2 mogu se vidjeti primjeri učionica u starom i novom dijelu škole u kojima su bili postavljeni osjetnici.

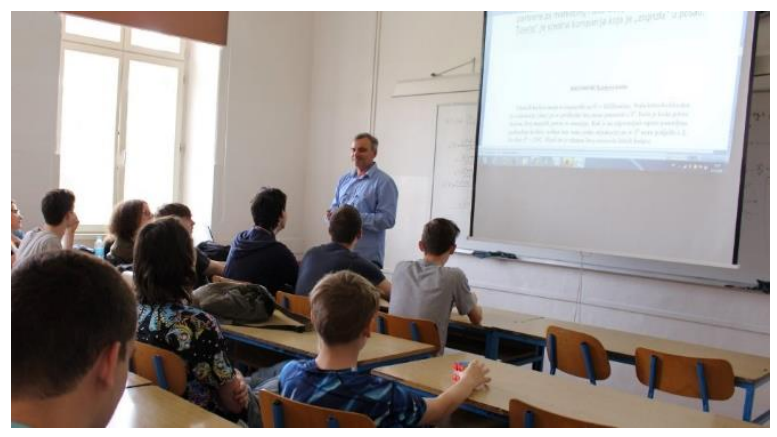

Slika 1. Primjer učionice u starom dijelu škole

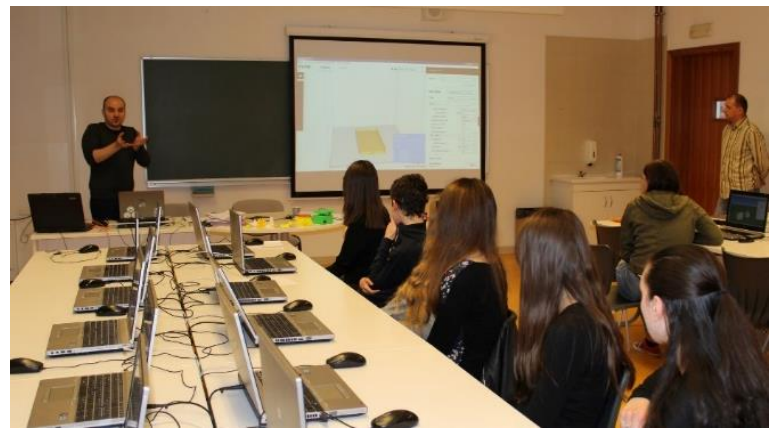

Slika 2. Primjer učionice u novom dijelu škole 
Zbog kratkog vremenskog razdoblja testiranja u ožujku i travnju 2019. godine i deficita dodatnih setova uređaja, osim rezultata anketa, primijenili smo i sljedeće uvjete:

- raspoređivanje osjetnika na način da su zastupljene sve glavne prostorne specifičnosti škole,

- raspoređivanje osjetnika na reprezentativnoj lokaciji u učionici (sredina razreda) u visini kukova,

- $\quad$ preporuka profesora o njihovom subjektivnom doživljaju pojedinih učionica za koje su smatrali da su mikroklimatski povoljnije/manje povoljne,

- odabir razreda pogodnih za izvođenje nastave, ali zbog prostornog rasporeda klupa ili veličine nepogodnih za pisanje pisanih provjera, $i$

- odabir razreda koji će pisati pisane provjere u vrijeme mjerenja mikroklimatskih čimbenika.

Konačno, kako bismo zbog vremenskog ograničenja barem djelomično ostvarili postavljeni cilj odlučili smo se za sljedeći pristup:

- $\quad$ nastavnici su za pojedine predmete izdvojili po dvije učionice od kojih su smatrali da je jedna mikroklimatski bolja, a druga lošija - osjetnici su postavljeni u učionice u kojima se odvija nastava iz pet različitih predmeta. Za svaki predmet odabrane su dvije učionice u kojima se održava nastava iz tog predmeta - jedan u mikroklimatski bolju i jedan u mikroklimatski Iošiju učionicu, i

- $\quad$ za svake dvije učionice pronaći barem 2 razreda kojima predaje isti nastavnik i koji će isti test (s obzirom na gradivo) pisati u vrijeme mjerenja mikroklimatskih čimbenika - jedan razred pisat će test u jednoj, a drugi u drugoj učionici.

Za ovakav pristup odlučili smo se zbog toga što smo htjeli dobiti rezultate koje možemo barem $u$ jednom dijelu uspoređivati. Naime, htjeli smo vidjeti poklapaju li se subjektivni doživljaji mikroklimatskih čimbenika profesora sa stvarnim mjerenjima te utječu li mikroklimatski uvjeti doista na uspjeh učenika na pisanim provjerama.

Utjecaj mikroklimatskih uvjeta na uspjeh učenika na pisanim provjera provjerit ćemo tako što ćemo usporediti rezultate na pisanoj provjeri jednake težine 2 podjednaka razreda kojima predaje isti profesor, ali u različitim mikroklimatskim uvjetima na taj smo način smanjili mogućnost utjecaja ostalih čimbenika na rezultate istraživanja.

\subsection{Prikupljanje podataka}

Nakon svih analiza, odabrani su sljedeći predmeti i učionice koje prikazuje tablica 1.

\begin{tabular}{|c|c|}
\hline Predmet & Učionice \\
\hline Matematika & 37,48 \\
\hline Hrvatski jezik & 10,13 \\
\hline Društveni predmeti & 41,44 \\
\hline Strani jezici & 72,76 \\
\hline Informatika & 80,82 \\
\hline
\end{tabular}

Tablica 1. Popis odabranih predmeta i učionica

Podaci prikupljani pomoću osjetnika pohranjivani su na lokalno računalo u Excel tablice, a prikaz cijelog Arduino seta može se vidjeti na slici 3.

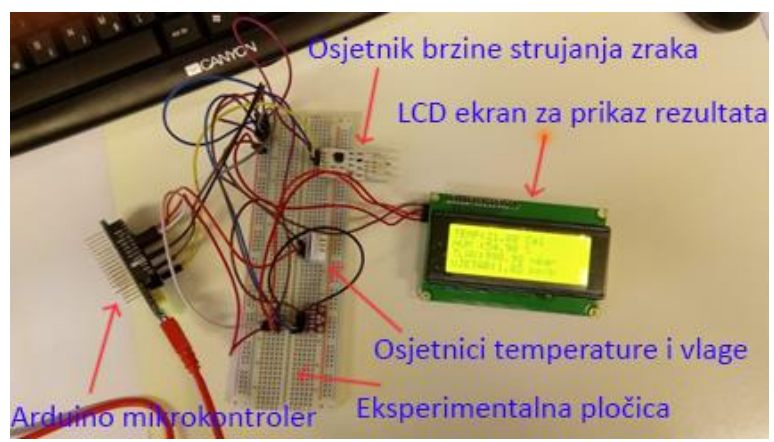

Slika 3. Set za prikupljanje podataka

Radi jednostavnosti, obrada podataka također je rađena u Excelu, a za prikaz podataka korišten je $\mathrm{i}$ alat Meta - Chart.

\subsection{Prikupljanje podataka i razvoj modela}

U prikazu rezultata najprije ćemo za svaki mikroklimatski čimbenik koji smo mjerili navesti prosječne globalne vrijednosti koje smo dobili mjerenjem. Nakon toga ćemo promatrati njihove vrijednosti za vrijeme pisanih provjera i na kraju ćemo za svaki par učionica usporediti mikroklimatske čimbenike i uspjeh učenika na pisanim provjerama. Bitno je napomenuti da zbog centralno kontroliranog sustava grijanja nije bilo moguće zasebno kontrolirati i mijenjati stanje mikroklimatskih čimbenika $u$ učionicama prilikom testiranja osim klasičnim putem, tj. otvaranjem prozora ili vrata zbog pregrijavanja ili subjektivne procjene „lošeg zraka“. Izračuni vrijednosti normama termodinamičkih sustava nisu provođene jer su nas interesirali rezultati zatečenog stanja prilikom provođenja testiranja. Upravo je to i jedan od razloga ovog istraživanja. Isto tako, zbog određenih specifičnosti, te vremenskih i ostalih projektnih ograničenja nisu provedena testiranja toplinske ravnoteže, npr. Fangerov PMV-PPD model (Ole Fanger, 1970), kvaliteta zraka primjenom CO2 osjetnika, kao ni provjera temperature zidova čijim bi vrijednostima dobili relevantnije zaključke. Međutim, s obzirom da je debljina zidova u starom dijelu škole više od $70 \mathrm{~cm}$, a u novom dijelu škole prilično je 
dobra izolacija, može se pretpostaviti da je prolazak temperature kroz njih zanemariv.

\section{Temperatura}

Temperatura je jedan od temeljnih i najčešće testiranih čimbenika mikroklimatskih uvjeta, ali ne najvažniji. Prema Pravilniku o zaštiti na radu [3, Članak 24] za mjesta rada predlaže se da je optimalna prosječna temperatura za rad bez fizičkog naprezanja između $20^{\circ} \mathrm{C}$ i $25^{\circ} \mathrm{C}$.

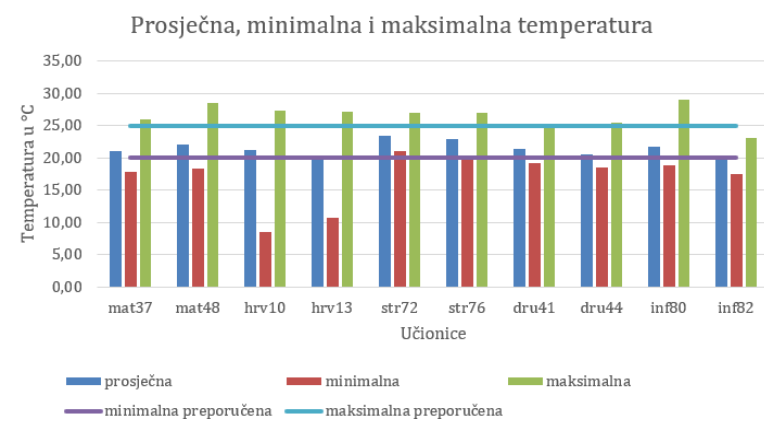

Slika 4. Prosječna, minimalna i maksimalna temperatura po učionicama

Slika 4 prikazuje kako je prosječna temperatura u svim učionicama unutar preporučenih vrijednosti za rad bez fizičkog naprezanja što bi značilo da većinu vremena učenici u promatranim prostorijama imaju optimalne uvjete za učenje. Također, maksimalna temperatura se postiže u učionici broj 80 , a minimalna u učionici broj 10 . Učionice 80 i 82 su jednako opremljene i smještene su na istom katu škole, ali na suprotnim stranama svijeta, pa vjerujemo da bi jedno od objašnjenja takvih rezultata mogla biti veća izloženost učionice broj 80 sunčevoj svjetlosti. Najniže minimalne temperature postižu se u učionicama koje su u prizemlju škole, u podacima iz mjerenja je vidljivo da se te temperature postižu $u$ jutarnjim satima kada su učionice bile prazne i bili su otvoreni prozori.

Slika 5 jasno pokazuje temperature za vrijeme pisanje testova po predmetima, kao i njihova odstupanja u postocima od prosjeka $i$ to naročito ukoliko se radi o većim odstupanjima od preporučenih.

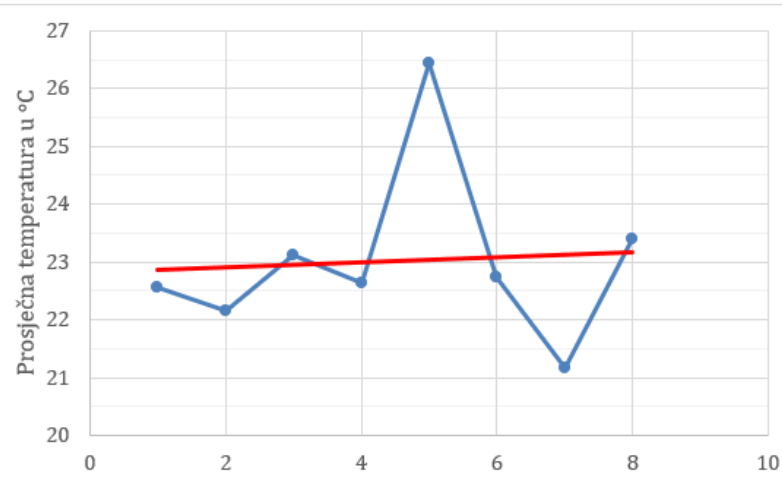

Slika 6. Prikaz vrijednosti prosječne temperature za vrijeme pisane provjere za sve razrede koji su u svojoj kategoriji (učionica i predmet) postigli najbolji rezultat

$\mathrm{Na}$ slici 6 izdvojene su prosječne vrijednosti temperatura u vrijeme pisanih provjera za sve razrede koji su u svojoj kategoriji (misli se na predmet i učionicu) postigli bolji rezultat u svojoj kategoriji. Dodavanjem linearne crte trenda možemo uočiti da je najbolja temperatura učenicima u vrijeme pisanja pisanih provjera bila oko 23 stupnja Celzija.

\section{Relativna vlažnost zraka}

Relativna vlažnost zraka također jedan od čimbenika mikroklimatskih uvjeta, fizikalna je veličina za iskazivanje udjela vodene pare u zraku (ili općenito $u$ plinovima). Izražava se omjerom parcijalnoga tlaka prisutne vodene pare i parcijalnoga tlaka zasićene vodene pare pri određenoj temperaturi i tlaku zraka u obliku postotka. Relativna vlažnost iznosi $0 \%$ kada je zrak potpuno suh, a $100 \%$ kada je zrak potpuno

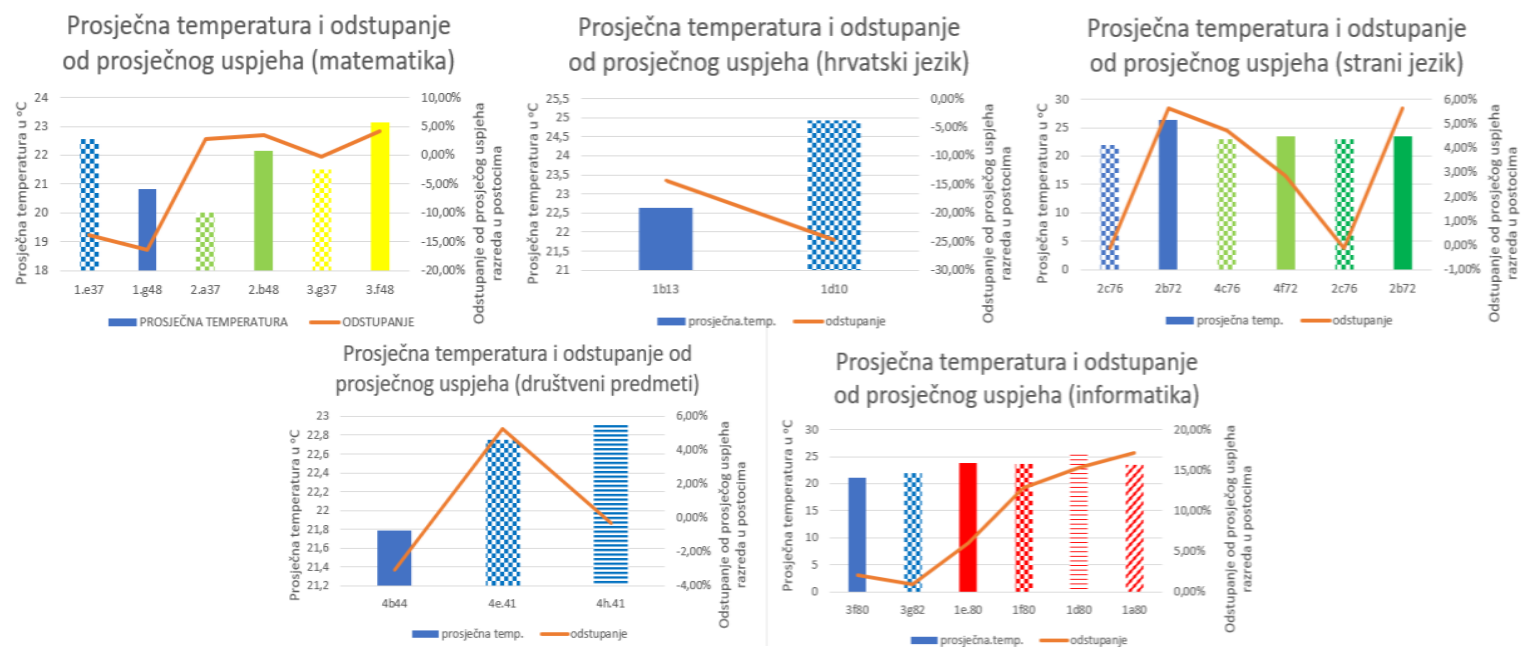

Slika 5. Temperature za vrijeme pisanja testova po predmetima i odstupanja u postocima od prosjeka uspješnosti 
zasićen vodenom parom.

Ljudi su osjetljivi na visoke vlažnosti jer za hlađenje organizam koristi znojenje gdje se kroz pore na koži, izlučivanjem znoja, oslobađa viška topline. Što je relativna vlažnost zraka veća, to će se znoj izlučivati sporije, a organizam je izložen opasnostima pregrijavanja. S druge strane, suhi zrak može uzrokovati suhu $i$ ispucalu kožu. Za kolektive, kao što je naša škola, važna je i informacija da suhi zrak uzrokuje isušivanje nosnica koje postaju osjetljive na viruse prehlade te se oni brže i lakše šire s osobe na osobu, kao i učestaliji razvoj nosnih polipa (Ehi \& Ozlece, 2018).

Prema Pravilniku o zaštiti na radu za mjesta rada [3, Članak 24] predlaže se da je optimalna relativna vlažnost za prostore $s$ klimatizacijom između $40 \mathrm{i}$ $60 \%$. Taj isti podatak o relativnoj vlažnosti navode i brojne institucije (,Proluft", 2019).

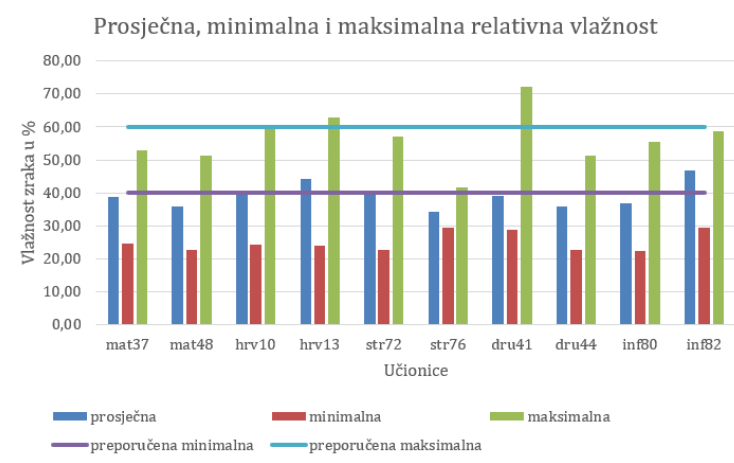

Slika 7. Prosječna, minimalna i maksimalna relativna vlažnost po učionicama

Slika 7 prikazuje kako je prosječna relativna vlažnost po učionicama na donjoj granici ili niža ispod preporučenih vrijednosti. Najviša prosječna relativna vlažnost je u učionici 82, a najniža u učionici 76 . Maksimalne vrijednosti jedva da prelaze gornju preporučenu granicu i najviša izmjerena vrijednost je u učionici 41. Ta činjenica ide u prilog tome da u promatranim učionicama nema opasnosti od razvoja plijesni niti opasnosti od pregrijavanja organizma učenika za vrijeme visokih temperatura. Međutim, minimalne vrijednosti čak u 9 od 10 učionica padaju ispod $30 \%$. Možemo zaključiti da je zrak suh u učionicama, što pogoduje širenju virusa prehlade. Također, suh zrak omogućuje razvoj nosnih polipa za koje je u prethodnim medicinskim istraživanjima dokazano kako utječu na koncentraciju i kognitivne sposobnosti ljudi (Ehi \& Ozlece, 2018). Postavljanjem ovlaživača zraka i posuda $s$ vodom mogla bi se poboljšati relativna vlažnost i time uvjete za širenje prehlade i razvoj polipa svesti na minimum.

Odstupanja u rezultatima pisanja testova po predmetima, kao i njihova odstupanja od prosjeka prikazuje slika 8.

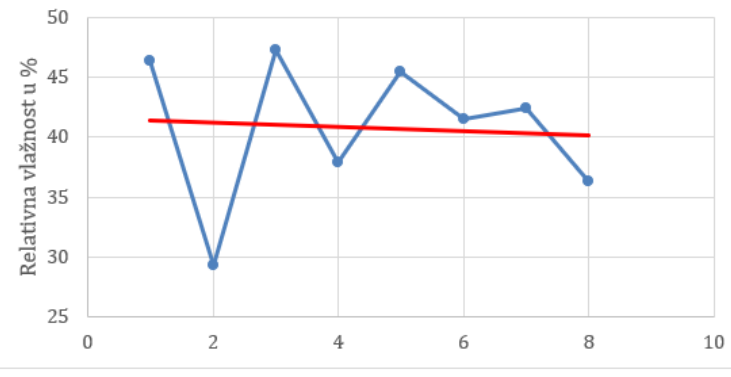

Slika 9. Prikaz vrijednosti prosječne relativne vlažnosti zraka za vrijeme pisanja testa za sve razrede koji su u svojoj kategoriji (učionica i predmet) postigli najbolji rezultat

Na slici 9 izdvojene su prosječne vrijednosti relativne vlažnosti zraka u vrijeme pisanih provjera za sve razrede koji su u svojoj kategoriji (predmet $\mathrm{i}$ učionica) postigli bolji rezultat. Dodavanjem linearne crte trenda možemo uočiti da je najpogodnija relativna vlažnost zraka učenicima u vrijeme pisanja pisanih provjera bila oko $40 \%$.

\section{Brzina strujanja zraka}

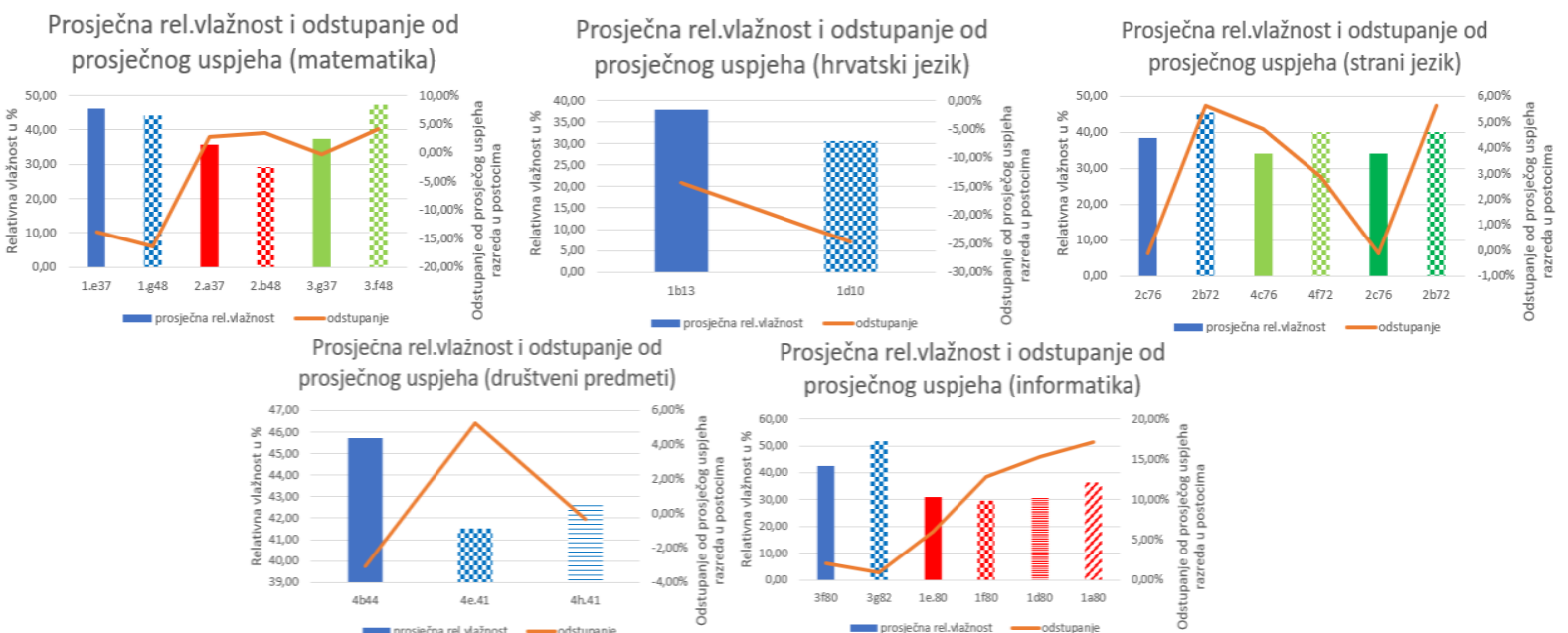


Brzina strujanja zraka je također jedan od iznimno važnih mikroklimatskih čimbenika na rezultate vrednovanja. Već ranije spomenuti pravilnik [3, Članak 24] navodi da brzina strujanja zraka na mjestima rada u zatvorenom prostoru ovisi o vrsti rada $\mathrm{i}$ tehnološkom procesu, a u sustavima $\mathrm{s}$ mehaničkom ventilacijom ne smije biti veća od 0,3 $\mathrm{m} / \mathrm{s}(1,08 \mathrm{~km} / \mathrm{h})$. S obzirom da su u mjerenom razdoblju temperature u Varaždinu varirale između $1{ }^{\circ} \mathrm{C}$ i $22^{\circ} \mathrm{C}$ („Accuweather", 2019) i da u učionicama nema mogućnost mehaničke ventilacije brzina strujanja zraka ne bi smjela biti veća od $0,15 \mathrm{~m} / \mathrm{s}$ $(0,54 \mathrm{~km} / \mathrm{h})$.

Registrirane prosječne brzine strujanja zraka prikazuje slika 10.

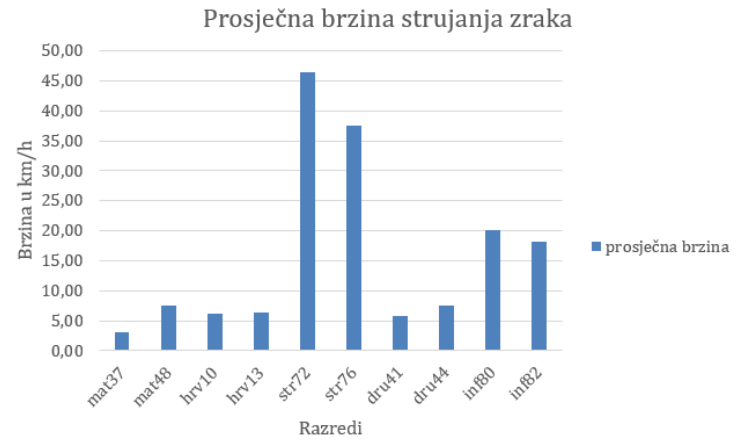

Slika 10. Prosječna brzina strujanja zraka po učionicama

Unatoč preporučenim brzinama strujanja zraka rezultati jasno pokazuju da su tijekom testiranog razdoblja u većini slučajeva bili otvoreni prozori kao posljedica „teškog“ zraka u razredima, više vanjske temperature, kao i nepostojanja mehaničke ventilacije. To je naročito zabilježeno u učionicama za strane jezike, a slijede ih učionice za informatiku. Svjesni smo situacije da su u periodima grijanja takvi načini provjetravanja neodgovarajući, ali drugi način trenutno nije moguć.

Slika 11 prikazuje odstupanja u postocima od prosjeka uspješnosti po predmetima i u odnosu na izmjerenu brzinu strujanja zraka.

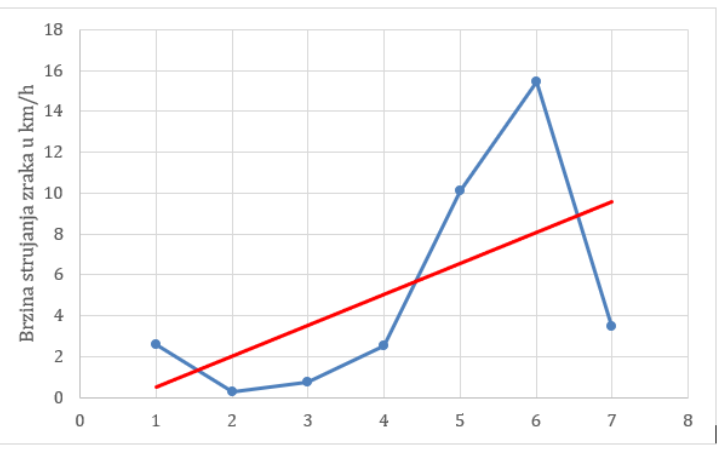

Slika 12. Prikaz vrijednosti prosječne brzine strujanja zraka za vrijeme pisanja testa za sve razrede koji su u svojoj kategoriji (učionica i predmet) postigli najbolji rezultat

$\mathrm{Na}$ slici 12 su izdvojene prosječne vrijednosti brzine strujanja zraka u vrijeme pisanih provjera za sve razrede koji su u svojoj kategoriji (predmet i učionica) postigli bolji rezultat. Dodavanjem linearne crte trenda možemo uočiti da je brzina strujanja zraka učenicima u vrijeme pisanja pisanih provjera bila oko $5 \mathrm{~km} / \mathrm{h}$, a što nas dovodi do zaključka da su prozori u učionicama redovito otvoreni prilikom pisanja kontrolnih zadaća neovisno o vanjskim vremenskim uvjetima.

\section{Zaključak i buduća istraživanja}

Temeljem ispitivanja temperature u učionici došli smo do zaključka da su bolji rezultat postizali oni razredi koji su za vrijeme pisanja pisane provjere

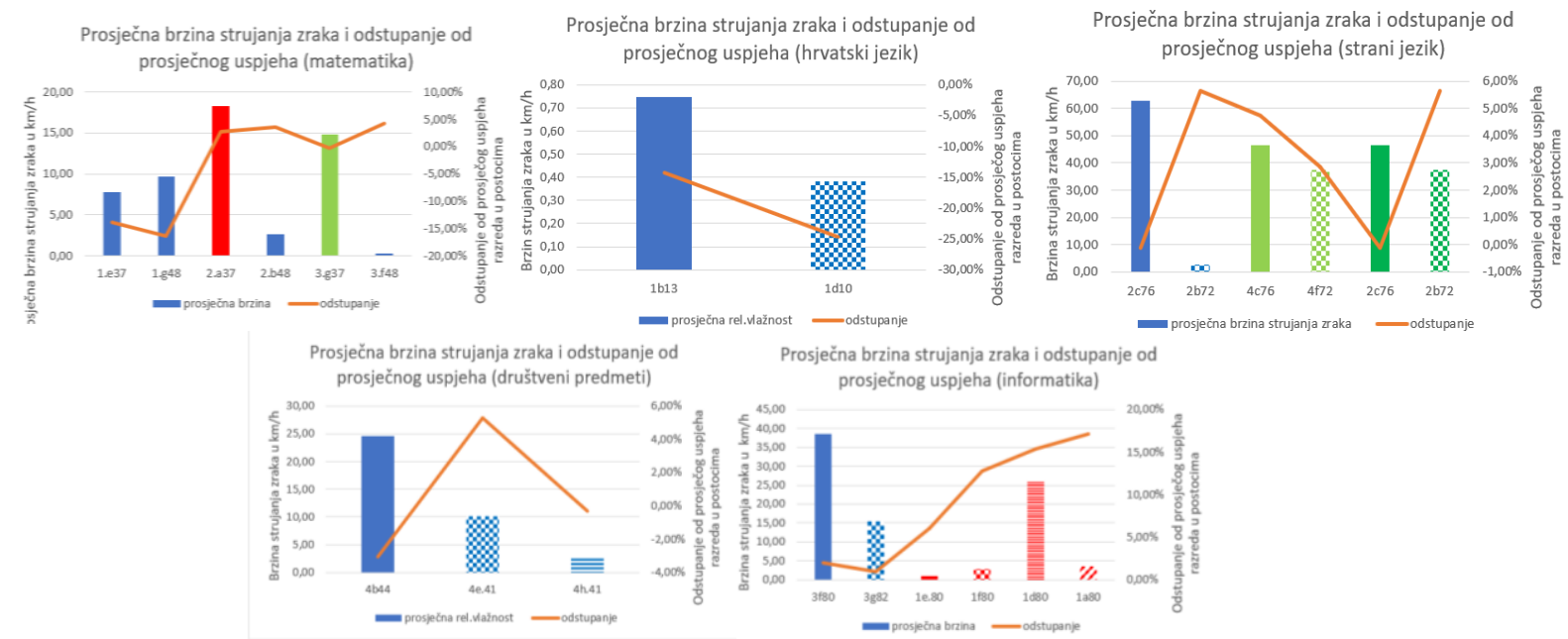

Slika 11. Brzina strujanja zraka za vrijeme pisanja testova po predmetima i odstupanja u postocima od prosjeka uspješnosti 
imali prosječnu temperaturu oko 23 stupnja Celzija. Dakle, ne možemo reći da viša temperatura znači i bolji uspjeh na pisanoj provjeri, već bi pravilnije bilo reći da temperatura bliža 23 stupnja Celzija ima pozitivan utjecaj na rezultate provedenih pisanih provjera u promatranom razdoblju. Rezultati analize vlažnosti zraka pokazuju da su bolji rezultat postizali oni razredi koji su za vrijeme pisanja pisane provjere imali relativnu vlažnost zraka oko $40 \%$. Većinu vremena je relativna vlažnost zraka bila niža od donje preporučene granice. Analiza strujanja zraka pokazuje da su bolji rezultat postizali oni razredi koji su za vrijeme pisanja pisane provjere imali brzinu strujanja zraka oko $5 \mathrm{~km} / \mathrm{h}$. Taj podatak možda ima objašnjenje $u$ tome što se otvaranjem prozora, osim poboljšanja kvalitete zraka, povećava i buka izvana koja smanjuje koncentraciju učenika kao negativan utjecaj. Takvi uvjeti ne zadovoljavaju norme za projektiranje termodinamičkih sustava i zato je jedan od temeljnih razloga ovoga istraživanja bio utjecaj takvih uvjeta na rezultate vrednovanja učenika.

Konačno, dobiveni rezultati nam pokazuju da bi u budućnosti trebali prilagođavati mikroklimatske uvjete u učionici prema preporučenima jer nepovoljni mikroklimatski uvjeti utječu na rezultate vrednovanja učenika. Isto tako, zbog navedenih rezultata možemo predložiti da se u budućnosti više vodi računa o projektiranju termodinamičkih sustava, tj. o uvjetima u učionici. To je naročito važno prilikom pisanja pisanih provjera znanja, a što ćemo sigurno i učiniti u našoj školi kako bismo dobivene rezultate mogli iskoristiti za prijedlog standarda mikroklimatskih uvjeta u učionicama koji osigurava najbolje rezultate pri vrednovanju učenika, a samim time povoljno djeluje na kognitivne, ali i afektivne procese. U ovom slučaju jedno od glavnih ograničenja je uzorak i vrijeme trajanja istraživanja. U budućnosti bi veći uzorak, kao i dulje vrijeme promatranja, sigurno dali preciznije rezultate. Sljedeće ograničenje koje je također važno spomenuti je homogenost razreda, iako su odabirani što sličniji razredi prema usmjerenju i prosjeku razreda.

\section{Literatura}

Accuweather (2019). Preueto 4.5.2019. sa https://www.accuweather.com/hr/hr/varazdin/1 15941/month/115941 ?monyr=4/01/2019\%20dan a\%204.5.2019

De Giuli, V., Zecchin, R., Corain, L., \& Salmaso, L. (2014). Measured and perceived environmental comfort: Field monitoring in an Italian school. Applied Ergonomics, 45(4), 1035-1047. https://doi.org/10.1016/j.apergo.2014.01.004

Ehi, Y., \& Ozlece, H. K. (2018). Electrophysiological assessment of the concentration and attention in patient with nasal polyposis. Asia Pacific Allergy, $8(3)$. https://doi.org/10.5415/apallergy.2018.8.e27

Grillo, O. C., La Scala, R., Sindoni, L., \& Anzalone, C. (2003). Survey on microclimatic condition of classroom. Annali Di Igiene: Medicina Preventiva e Di Comunità.

Hamzah, B., Mulyadi, R., Amin, S., \& Kusno, A. (2020). Adaptive thermal comfort of naturally ventilated classrooms of elementary schools in the tropics. IOP Conference Series: Earth and Environmental Science, 402(1). https://doi.org/10.1088/17551315/402/1/012021

Ole Fanger, P. (1970). Thermal comfort. Analysis and applications in environmental engineering. Copenhagen: Danish Technical Press.

Proluft (2019). Preuzeto 4.5.2019. sa https://proluft.hr/savjeti-iblog/savjeti/kucanstvo/optimalna-temperatura-ivlaznost-ugodan-boravak-46

Vučinić, J., Vučinić, Z., \& Pejnović, N. (n.d.). KLIMATSKI UVJETI RADNOG OKOLIŠA.

Zakon o zaštiti na radu (2019). Preuzeto 5.5.2019. sa https://www.zakon.hr/z/167/Zakon-o-zaštiti-naradu

\section{Analysis of the impact of microclimatic conditions in classrooms on students' assessment results}

\section{Abstract}

In the 2018/2019 school year at the Prva gimnazija Varaždin in Varaždin, a study of microclimatic conditions was conducted on the results of student evaluation. The goal of our project is to prove or disprove the impact of the microclimate on student performance in specific situations, that is, in the usual way of knowledge testing: written tests. Given that state examinations are currently based on such a model of assessment, we believe that it is important to identify a correlation between the microclimate and student performance in the knowledge test and, if confirmed, to contribute to the development of standards for the existing school premises or the construction of new ones. The microclimatic conditions tested were temperature, relative humidity and airflow. Testing was conducted in 10 different classrooms and five different subjects or 
groups of subjects. The results indicate poorer evaluation results at greater deviations from the recommended values of observed microclimatic conditions.
Keywords: Prva gimnazija Varaždin; indoor microclimate conditions; thermal comfort; experimental measurements; students' evaluation. 